\title{
Information on huchen, Hucho hucho (L.), from historical Polish sources
}

\author{
Stanisław Cios
}

Received - 13 January 2015/Accepted - 24 February 2015. Published online: 31 March 2015; Inland Fisheries Institute in Olsztyn, Poland Citation: Cios S. 2015 - Information on huchen, Hucho hucho (L.), from historical Polish sources - Arch. Pol. Fish. 23: 17-24.

\begin{abstract}
This paper presents historical information on the Danube huchen, Hucho hucho (L.), in Polish sources from the sixteenth to early twentieth centuries in the Danube, Prut, Dniester, and Vistula river basins. These accounts concern the historical distribution of the species and its economic importance, culinary value, fishing methods, and artificial reproduction and propagation. The occurrence of huchen in the Dniester River basin until the beginning of the eighteenth century merits special interest, because this river is not mentioned by any modern source on the natural distribution of this species. The extinction of the huchen in this river can likely be attributed to anthropogenic changes in the environment that were associated mainly with agricultural development.
\end{abstract}

Keywords: economic importance, endangered species, fishing methods, historical data, Hucho

\section{Introduction}

The huchen, Hucho hucho (L.), is classified as a critically endangered fish species. Growing international interest in the protection and sustainable management of this species (Witkowski and Kapusta 2013, Ihuț et al. 2014) requires, among other things, acquiring the best possible knowledge on all aspects of its biology and relationship with humans, including its historical experience. The purpose of this paper is

\footnotetext{
S. Cios [ڤ]

ul. Stryjeńskich $6 \mathrm{~m} 4$

02-791 Warszawa, Poland

e-mail: stcios@hotmail.com
}

to render available to international researchers information on huchen from old Polish sources. Since no such synopsis exists. This paper includes information pertaining mainly to waters located within the current borders of Poland and western Ukraine. The only historical Polish paper on huchen that was written in one of the major European languages is that by Kulmatycki (1931). The information presented in this paper sheds light on such issues as the distribution of the species, economic importance, culinary value, fishing methods, and artificial reproduction in the past.

\section{Material and methods}

This paper is part of the author's research on the history of fisheries in Poland from the Middle Ages to the beginning of the twentieth century based on the analysis of all types of printed verbal accounts, including chronicles, diaries, memoirs, poetry, stories, newspapers, medical and natural history treatises, financial documents, cookbooks, etc. Most of the information in these sources pertains to the territory of Poland after the Union of Lublin in 1569, and as such it also includes territories currently located in Ukraine. The verbal heritage is especially rich with respect to western Ukraine, where a sizable and

\footnotetext{
C Copyright by Stanisław Sakowicz Inland Fisheries Institute in Olsztyn.

C 2015 Author(s). This is an open access article licensed under the Creative Commons Attribution-NonCommercial-NoDerivs License

(http://creativecommons.org/licenses/by-nc-nd/3.0/).
} 
well-educated Polish community was present, in particular in the city of Lviv, or Leopolis.

Accounts relating to the huchen, especially when compared to trout, Salmo trutta L., salmon, Salmo salar L., and grayling, Thymallus thymallus (L.), are relatively few; however, some of them are extremely valuable because of their age and the contribution they make to our knowledge of various aspects of this fish. No similar broad analysis of historical sources on huchen in Europe is known to this author, and some of these findings have been presented previously in Polish (Cios 2005, 2007a, 2014).

\section{Prut River basin}

The oldest references to huchen in Polish sources are found in a register of expenses incurred in 1591-1592 after the purchase of the small town of Kołaczkowce (currently Kulaczkivci, Ukraine) by a nobleman (Anonymous 1888). The town is on the Czarniawka River, a tributary of the Prut River that flows through the city of Vinograd.

Huchen and brown trout are mentioned nine times, stone loach, Barbatula barbatula (L.), twice, and another fish once in the register. All the huchen were probably caught from October to December 1591, while the trout were likely caught from at least June until December of the same year.

The entries in the register are general and usually lack precise information about the place and time of purchase. Some references to the city of Kołomyia by the Prut River could suggest that many fish were caught and bought in this locality. It cannot be ruled out that some fish where bought in the region of the Dniester River drainage basin (Fig. 1).

Altogether, the register mentions the purchase of 77 huchen and 650 trout, as well as an undefined number of other fish. Records pertaining to 76 huchen and 620 trout were analyzed
Table 1

Huchen $(H$. hucho) and trout (S. trutta) in the register from 1591

\begin{tabular}{llll}
\hline \hline Species & $\begin{array}{l}\text { Number of } \\
\text { fish }\end{array}$ & $\begin{array}{l}\text { Expense } \\
\text { (florin and } \\
\text { groschen) }\end{array}$ & $\begin{array}{l}\text { Average } \\
\text { price } \\
\text { (groschen) }\end{array}$ \\
\hline \hline Huchen & 51 & 2 fl., 19 gr. & 1.5 \\
& 5 & 1 fl., 2 gr. & 6.4 \\
& 3 & 21 gr. & 7.0 \\
& 2 & 15 gr. & 7.5 \\
& 3 & 26 gr. & 8.2 \\
& 5 & 2 fl. & 12.0 \\
& 2 & 26 gr. & 13.0 \\
& 2 & 1 fl. & 15.0 \\
& 3 & 3 fl., 17 gr. & 35.7 \\
& 50 & 10 gr. & 0.20 \\
& 350 & 3 fl., 4 gr. & 0.27 \\
& 90 & 24 gr. & 0.27 \\
\hline \hline
\end{tabular}

further, and entries lacking prices for the fish were omitted. The data on the number of fish, the total price, and the average price per fish ( 1 florin equaled 30 groschen) is presented in Table 1.

The average huchen price was 5.21 gr. (496 gr. $\div 76$ fish), and that for trout was 0.30 gr. (188 gr. $\div 620$ fish). Therefore, the average huchen was 17 times more expensive than the average trout. Assuming that most of the trout were approximately

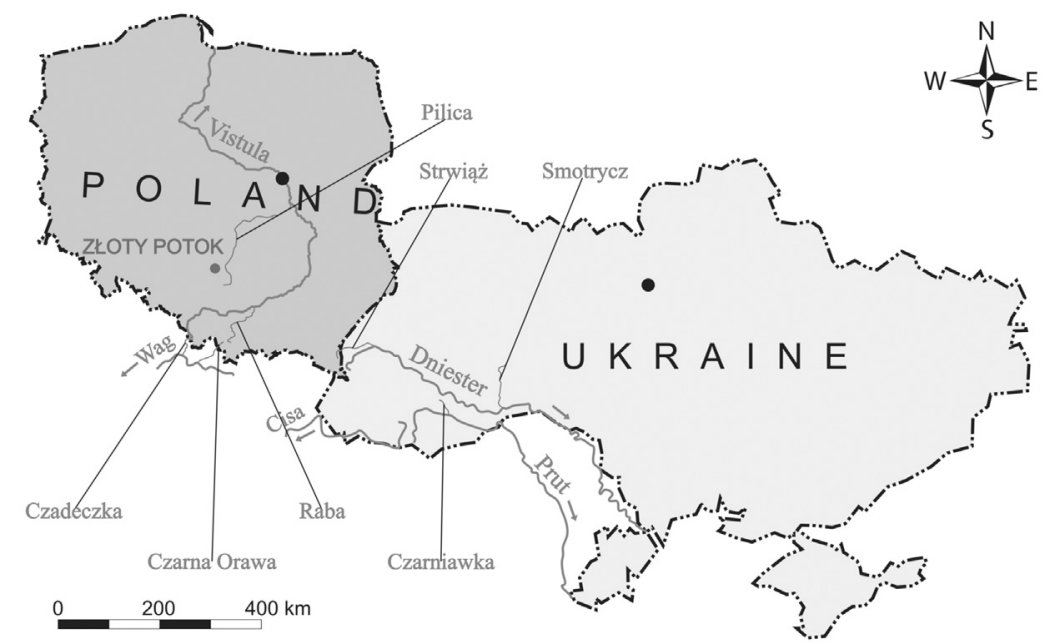

Figure 1. Waters mentioned in the context of huchen in historical Polish sources. 
100 grams (approximately $20 \mathrm{~cm}$ TL; the small size can be inferred from the large number of trout and the description accompanying 350 fish as "small”), then the average huchen weighed approximately 1.5 $\mathrm{kg}$. In consideration of the average price spread, huchen were generally in the range of $0.5-10 \mathrm{~kg}$. In practice, some of the fish were probably smaller, and some were probably larger. Most of the trout were in the range of 70-150 grams, but there were probably a few fish larger than $0.5 \mathrm{~kg}$.

The results of the calculations can be considered to be realistic based on two assumptions: 1) the value of trout and huchen meat was equal; 2) there were no seasonal or geographical differences in the price of fish. The high value of huchen is confirmed by the fact that the fish were destined four times for the prince (trout - three times). In other cases the fish aren't earmarked. For comparison, for a noble lady trout were bought once, stone loach twice and crayfish once, while for a meeting between a priest and a prince some undetermined fish. Therefore, huchen was a fish preferred by the nobility, while the small numbers indicate that probably all specimens on sale were bought.

The large number of huchen (51) and trout (350, 130, 90, and 50) purchased on a single occasion are of interest. Probably most, or even all, of these fish were probably conserved by smoking or marinating as was the historical tradition in the mountains with the fish species of salmon, trout, and grayling.

The next reference to a huchen is contained in the travel diary of Rafał Leszczyński, a Polish envoy to Turkey, in 1700. It reads "The waters of the Prut River are healthy and abound with fish; the Czeremosz River has still more fish, and salmon are caught there" (Czarmańska and Zydorek 1998, 122). The author of the diary is probably Michał Bułhak from Lithuania. Evidently, huchen was a fish unknown to him, so he used the name salmon. It seems that the envoy and his entourage were served huchen during their stay in the region.

The third reference is presented by Rzączyński (1742, 211), who writes that in the Prut River "głowacica, similis traditur esse Truttae majori, sed nullis conspersus maculis, superans longe mensuram cubiti" huchen is similar to a large trout, but without the spots and is longer than an ellwand). This information was later copied by Duńczewski (1768), but he confused the description by adding information about the species capitonem fluviatilem majorem, referring to chub, Squalius cephalus (L.), from Schwenckfeld's (1603) work on fish in the Lower Silesia region. The reason for the confusion was the fact that the Polish name for huchen is gtowacica, derived from gtowa, meaning head, just like caput.

The second half of the nineteenth century abounds with references to huchen stemming from the strong ichthyological and ethnographic interest in the southeastern parts of Poland. The earliest author was Maksymilian Nowicki (1877), the founder of the National Fisheries Association in Kraków in 1879. When he was in Żabie, which is currently Verhovina, asking about local fish, he learned that a large, tasty fish thrives in the Czeremosz River that is referred to by local Huculs as hołowatycia. Thanks to the assistance of a priest, he obtained a young specimen of huchen, $16 \mathrm{~cm}$ in length caught by rod and line. He was told that the fish in the Czeremosz can reach 28-36 inches, fetching a high price of 6 to 12 zloties. The fishermen in Żabie caught huchen mainly at night in the fall using a torch and spear; they also used landing nets, rods, and dynamite. The fishermen learned how to startle fish in pools by attaching wooden rings to lines and placing them in fast flowing water. The rings would rattle and startle the fish prompting them to move out of deep water. He also noted that the greatest threat to huchen was river logging, which killed the fish. In his later papers, Nowicki (1880a, 1889) reports that, since the flood of 1867, huchen had disappeared from the Prut River upstream from the city of Delatyn, and that the demand for huchen was high due to its tasty flesh, and thus it fetched high prices. He also reports that because of its predation on trout the idea of introducing huchen in the Vistula and Dniester rivers was abandoned. The tackle used for startling huchen and spears from the Kosów area were presented during an ethnographic exhibition in the city of Kołomyja (Anonymous 1880). 
Wajgiel $(1877,80)$ briefly stated that "large trout called huchen” are among the fish in the Prut River. In a later publication, Wajgiel (1887) refers to huchen noting that it is much rarer than trout. The disappearance of the huchen in the Prut River was mentioned previously by C.K. (1879). He states that a few years earlier there were many huchen in pools near Dora, but that they disappeared after flood waters passed through. He postulated to reproduce artificially the huchen using material originating from the Czeremosz River. Bojarski (1880) is the first author to note the presence of the huchen in still waters. He reports that, according to locals, huchen about one fathom in length inhabit Lake Szybeny in the upper part of the Czeremosz River. Bąkowski (1882) reports that local informants in Żabie claim huchen can reach lengths of one meter or more. He notes the disappearance of the fish in the Prut River, and he also states that the fish was caught only at night with a torch and a spear. Fiszer (1893) reports that huchen reaching a length of $1.5 \mathrm{~m}$ occur in pools in the Prut and Czeremosz rivers, as well as in some lakes in the mountains. Huchen feed mainly on trout. Since they live in deep pools, they are very difficult to catch. Therefore, huchen were not an object of regular fishing and commerce in contrast to salmon in other parts of Poland. Szuchiewicz (1902, I:265-266) in his ethnographic account of the Huculs, describes spear fishing for huchen. The spear handle was made of a spruce tree 3 to $4 \mathrm{~m}$ long. At the thicker end, 2-3 layers of branches were left uncut. The metal head was usually made by a Romani smith. Fishing was done in fall on foot or from a boat. After piercing the fish, usually in the occiput, the handle was immediately released. The fish would swim away, but the branches would hamper its movements and, after its death, the location of the catch would be indicated by the spear protruding out of the water. Szuchiewicz also states that huchen meat is delicious. In an account from the 1920-30s, Rymarowicz (2011) states that in Żabie a local businessman always greeted high level delegations of officials with Tokaji wine and huchen, even though the fish was protected.

\section{Danube River basin}

In the Polish version of the work by Johann Andreas Christian Löhr (1822, 159) the translator (Aleksander Kuszański) notes the "we will not mention here anything about the species called chucha living only in the Danube River"; it seems that the fish was unknown to the translator.

In a book on old Polish customs, Gołębiowski $(1830,38)$ mentions that "salmon from Gdansk, the Danube and the Cisa [Tisa] rivers" were most highly appreciated. Evidently, in the case of the last two rivers he is referring to huchen. Gołębiowski was a librarian, who lived for many years in Poryck (currently Pavlivka in the Volyn region in Ukraine) and in Puławy by the Vistula River. The source of his information remains unknown. It is possible that his opinion reflects personal contact with huchen in Western Ukraine. However, it cannot be excluded that this statement was also based on some unknown historical documents to which he had access. This is likely since he refers extensively to other authors in his publication.

Cios (1994) (the father of this paper's author) mentioned an account of a large huchen of approximately $30 \mathrm{~kg}$ caught in 1947 in the Czarna Orawa River. As a farmer from the town of Jabłonka was going to work in the fields one spring day, he noticed a huge fish in the shallows moving upstream. He threw a heavy harrow on the fish and later killed it with a prong. News of the catch spread, and the farmer had to share the fish with the local authorities. Cios also shares a personal account from the same year of catching with a lure a huchen approximately $75 \mathrm{~cm}$ in length in Jeleśna Woda, a tributary of the Czarna Orawa. This is apparently the only historical account on record in Polish sources of huchen in Jeleśna Woda.

Under the heading Esox, Falimirz (1534) states that in the Danube River "there is a fish called tasz, which resembles a salmon with a lower jaw bent like an eagle's, in which there is a hole through which food is taken. Its meat is red, but not so good as that of salmon. In Polish it is called klepień." According to 
Rostafiński (1900), the name tasz (from the German Lachs) was used to refer to huchen. This interpretation is open to criticism, since Falimirz (1534), whose text was based on popular herbaria of his time, especially on Herbarius and Ortus sanitatis (Kołodziejczyk 1957), mistakenly included salmon among the fish in the Danube River. From the work by Cuba (1497, cap. XXXV), it is clear that in the Middle Ages the name Esox was applied to beluga, Huso huso (L.), in the Danube and to salmon in general.

\section{Dniester River basin}

Sebastian Petrycy (1613) was a physician who lived in the city of Lviv by the Dniester River from 1595 to 1601. In his publication on the plague, he briefly refers to the salubrious value of fish, by repeating the traditional view that riverine fish are healthier than those from still waters. However, as regards the fish from rivers with stony bottoms he recommended "stone loach, trout, and huchen from the Dniester River." Undoubtedly, he must have known the huchen well since he lived by this river.

Huchen from the Dniester River drainage area are also mentioned by Gabriel Rzączyński (1742, 199, 211), a Jesuit naturalist, who observes that "Smotrycz Podoliae fluvius intra rupes effusus in Tyram rapidum defluit, truttas, cobites \& gtowacicas nutrit" (the Smotrycz River in the Podole region, which flows rapidly between rocks, feeds trout, stone loach, and huchen). Duńczewski (1767) repeats this information, but he replaces huchen with bullhead (Cottus sp.). Unaware of huchen, he became confused because the Polish names of both of these fish are similar - gtowacica and gtowacz, respectively.

These accounts posed a challenge to some later naturalists since no other historical source mentions the presence of the huchen in the Dniester River. Belke $(1859,61)$, who wrote on the natural history of the Podole region, recognized this problem since he assumed that the huchen mentioned by Rzączyński (1742) were actually bullhead. However, the name głowacz in general was unknown in the eastern part of Poland. According to Nowicki (1880b) bullhead was called babka there.

Kessler (1856) also had a problem since he omits huchen from his description of fish in the Dniester River, while he briefly mentions that trout had thrived in the Smotrycz River during the time of Rzączyński, but that "now it is no longer there.” Indeed Rzączyński $(1721,141)$ wrote about the Smotrycz River, as follows: "Camenecum Podoliae circum fluens, Tyram ingrediens, aquatilibus annumerat truttas plusquam ulnares" (close to the town of Kamieniec Podolski there are trout longer than an ellwand). Rzączyński's home region was the Podole, and he lived in the cities of Lviv, Jarosław, and Łuck. Therefore, it can be assumed that his information is original, and that he was knowledgeable about the salmonids he mentions.

\section{Vistula River basin}

Specimens of huchen (rudopstrag) preserved in oil from the hatchery in Złoty Potok were among the items presented during the agricultural exhibition in Warsaw in 1874 (Anonymous 1875). Złoty Potok was an estate owned by the aristocratic Krasiński family and located near the Wiercica River, a tributary of the Pilica River in the Vistula River drainage basin (Fig. 1). This is the oldest known information in Poland on huchen culture in fish ponds and also of its occurrence in the Baltic Sea drainage basin. From at least 1851 there was a fish farm in Złoty Potok that focused on salmonids, and which was modernized and expanded in 1881. Very little is known on its early activities. From the account mentioned, it seems that it used imported material, among which was huchen, as the basis for its operations. Perhaps advertisements in journals like the one from 1866 (presented below) promoted the purchase of foreign materials (eggs).

There is also an account of the catch of a huchen $80 \mathrm{~cm}$ long (probably TL) in July 1900 in the Raba River, a tributary of the Vistula River; it is also suggested that the eggs were brought by a water bird (sic!) or by man together with the eggs of other 
salmonids (Anonymous 1900). Rozwadowski (1903) writes that attempts were made to introduce the huchen in other rivers than in the Black Sea drainage area, and he mentions the Dniester and its tributaries, as well as the Vistula River, but the results were unsuccessful. Unfortunately, nothing is known about these stocking attempts; moreover, the National Fisheries Association in Kraków was against introducing huchen into other rivers because to its strong predation pressure on trout.

\section{Other accounts}

There are other general references to huchen in the Polish ichthyological literature. Kluk (1780) mentions the fish pstrag brudny (Salmo hucho), which translates literally as dirty trout. Leśniewski (1837) uses the name rudopstrag (ginger trout) and adds that the fish is very rare in Poland. Both of these accounts are based on foreign sources, while the vernacular names probably derived from the German Rothuchen. The common Polish name gtowacica was unknown to these authors.

In articles on artificial fish reproduction (Anonymous 1853, 1859) based on foreign sources (the first is a translation of a paper by Coste 1853), there is a reference to this method used with various fish species, including the Danube salmon. Danube salmon (Huchen) is included in a price list of fish eggs in the city of Salzburg (Anonymous 1866). This information is also based on foreign sources.

\section{Discussion}

The relatively few references in the historical Polish literature to huchen as compared to those regarding salmon, trout and grayling and some of the information in the accounts discussed in this paper indicate that huchen was not a widely-known fish in Poland despite its large size and high culinary value. Apparently, it was commonly mistaken for salmon, especially by persons traveling through the Prut River drainage area. Knowledge of this fish was restricted mainly to people living in the areas where the fish thrived. Lack of knowledge of huchen, as well as similar vernacular names of other fish (bullhead and chub), often led to confusion even among persons educated in natural history. One of the reasons for this was the lack of inter-regional huchen trade. This fish, which generally was not available in large numbers, was sold and consumed only locally.

The available sources indicate that huchen was not included in the feudal system of seigniorial dues as were salmon and trout in other parts of Poland, and the register from 1591 indicates that huchen was usually destined for the market. Again, the reason should be sought in the relatively small population of huchen, which rendered it difficult to plan catches. The abundance of trout probably reduced fishing pressure on huchen, but it did not serve as a full substitute for human consumption. It seems that the huchen was valued much more highly than was trout, not least thanks to it sheer size.

The data from 1591 indicates that fishing pressure on trout and huchen was strong throughout the year, presumably mainly with nets. This fishing pressure contributed to keeping the huchen population at low levels. It seems that large huchen were caught individually, especially with spears. This practice was still common in the first half of the twentieth century, as evidenced on the postcard from Kosów by the Rybnica River, a tributary of the Prut River, from 1925 (Fig. 2).

From the faunistic point of view the most important information concerns the historical occurrence

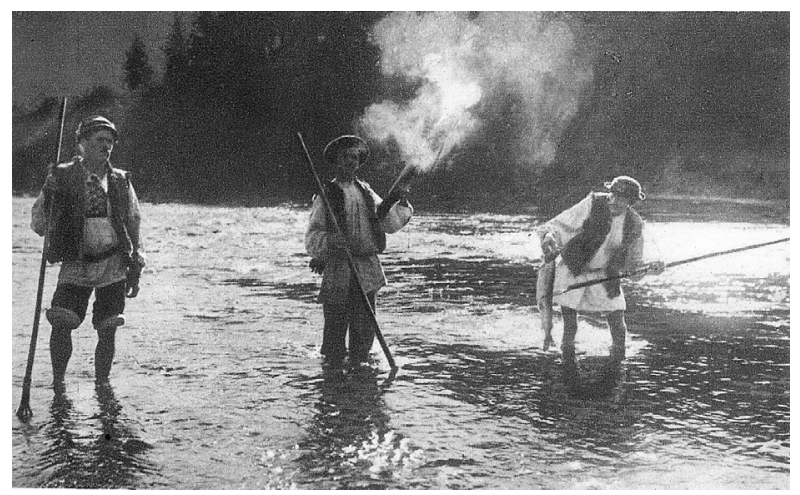

Figure 2. Huchen fishing on a postcard from Kosów in the Prut River drainage area (photograph by M. Seńkowski). 
of the huchen in the River Dniester and some of its affluents still early in the $18^{\text {th }}$ century. This river system is not mentioned in any modern publication on the distribution of huchen in Europe. One of the consequences of this finding is that the Strwiąż River that flows from Poland to the Dniester could be the third river, in addition to the Czarna Orawa and Czadeczka rivers, within the current borders of Poland in which there was an autochthonous huchen population. This, in turn, could have further implications for the management and protection of the species, including possible reintroduction.

The disappearance of huchen from the Dniester River and trout from the Smotrycz River was likely caused by agricultural development and deforestation in historic times that led to the deterioration of conditions for salmonids. A similar process occurred with the salmon and trout in the Vistula River drainage basin and in northern Poland (Cios 2003, 2007b, Radtke and Bartel 2011). Habitat deterioration is the single most important factor negatively affecting huchen (Witkowski et al. 2013, Ihuț et al. 2014).

Information indicating that attempts were made to reproduce huchen artificially in the early years of the development of such methods in the mid nineteenth century is particularly interesting. Much more information on this issue remains to be revealed in various European sources from this period (e.g., Coste 1853, Anonymous 1868). To date, the oldest known information on huchen propagation dates from 1876 (Witkowski et al. 2013). It seems that at the turn of the $19^{\text {th }}$ and $20^{\text {th }}$ centuries artificial breeding and rearing the huchen in manorial ponds became a common practice over a broad area (Hanel et al. 2013, Muhamedagić and Habibović 2013).

The lack of in-depth historical studies on huchen in Europe currently makes it difficult to compare the various aspects of the relationship between humans and huchen with other regions. It also appears that the spear fishing was widespread (Sauvage 1883, Witkowski et al. 2013).

Acknowledgments. The author would like to thank Maksym Łaszewski for his kind assistance in preparing the map.

\section{References}

Anonymous 1853 - The science of stocking with young fish, by Mr. Coste - Ziemianin 11: 214-220 (in Polish).

Anonymous 1859 - Artificial fish reproduction - Ziemianin 4: 298-310 (in Polish).

Anonymous 1866 - Price list of fish eggs - Gazeta Przemysłowa 36: 148 (in Polish).

Anonymous 1868 - Pisciculture - In: Chambers's encyclopaedia: a dictionary of universal knowledge, London 7: 557-560.

Anonymous 1875 - Salmon - Gazeta Warszawska 102: 2 (in Polish).

Anonymous 1880 - Catalog of artifacts of the ethnographic exhibition of the Czarnohora Section of the Tatrzańskie Society including the districts of Kołomyjski, Kossowski, Śniatyński, Horodeński, Zaleszczycki, and Borszczowski and an exhibition of mountain products - Czcionkami Drukarni Ludowej, Lwów, 22 p. (in Polish).

Anonymous 1888 - Register of expenses for the needs of the prince in Kołaczkowce and Kropiec and what was given to him - Akty izdavaemye Vilenskoű Arheografičeskoű Kommissieű 14: 431-433 (in Polish).

Anonymous 1900 - Huchen in the Raba River - Okólnik Rybacki 48: 9 (in Polish).

Bąkowski J. 1882 - Notes from a trip to Czarnohora Wędrowiec 7: 104-106, 10: 152-153 (in Polish).

Belke G. 1859 - Natural history of Kamieniec Podolski Drukarnia Gazety Codziennej, Warszawa, 114 p. (in Polish).

Bojarski J. 1880 - Fishing notes. Tributaries of the Czeremosz Czarny and their fish - Przyrodnik 3(2): 28-29 (in Polish).

C.K. 1879 - A few words on fishing and fish in the Prut River Łowiec 2(5): 69-70 (in Polish).

Cios J. 1994 - Recollections from Orawa in 1947 - Pstrąg \& Lipień 2(3): 10-12 (in Polish).

Cios S. 2003 - Comments on the occurrence of trout, salmon, and grayling in Polish waters in the past - Rocz. Nauk. PZW 16: 17-32 (in Polish with an English summary).

Cios S. 2005 - Huchen in Polish literature from the sixteenth to the nineteenth centuries - Prz. Ryb. 30: 56-64 (in Polish).

Cios S. 2007a - Fish in the life of Poles from the tenth to the nineteenth century - Wyd. IRS, Olsztyn, 251 p. (in Polish).

Cios S. 2007b - Further historical information on the occurrence of salmon in the Bug River basin - Prz. Ryb. 32: 78-80 (in Polish).

Cios S. 2014 - Historical information from the sixteenthsixteenth century on the huchen in Western Ukraine Prz. Ryb. 38: 40-41 (in Polish).

Coste J. 1853 - Pisciculture. Memoire sur les moyens de repeupler les eaux de la France - Comptes rendus de l'Académie des Sciences 36: 237-246.

Cuba J. [ca. 1497] - Ortus sanitatis - Johann Prüss, [Strasburg].

Czarmańska I., Zydorek D. (eds.). 1998 - The legation of Rafał Leszczyński to Turkey in 1700 roku - Urząd Miasta, Leszno, 278 p. (in Polish). 
Duńczewski S. [1767] - Information on rivers in the Polish Kingdom - Kalendarz polski y ruski na rok Pański 1768. [Drukarnia Zamoyska S. Jana Kantego, Zamość] (in Polish).

Duńczewski S. [1768] - Information on rivers, ponds, lakes, fish, continued - Kalendarz polski y ruski na rok Pański 1769. [Drukarnia Zamoyska S. Jana Kantego, Zamość] (in Polish).

Falimirz S. 1534 - On herbs and their utility - Florian Vnglerius, Kraków (in Polish).

Fiszer Z. 1893 - Fisheries relations on the Prut and Czeremosz rivers - Okólnik Rybacki 9: 36-41. (in Polish).

Gołębiowski Ł. 1830 (reprint 1983) - Houses and mansions A. Gałęzowski, Warszawa, 296 p. (in Polish).

Hanel L., Lusk S., Andreska J. 2013 - Huchen in the Czech Republic: A review - Arch. Pol. Fish. 21: 143-154.

Ihuț A., Zitek A., Weiss S., Ratschan C., Holzer G., Kaufmann T., Cocan D., Constantinescu R., Miresan. V. 2014 Danube salmon (Hucho hucho) in Central and South Eastern Europe: A review for the development of an international program for the rehabilitation and conservation of Danube salmon populations - Bulletin UASVM Animal Science and Biotechnologie 71(2): 86-101.

Kessler K. 1856 - Natural history of the provinces of the University District of Kiev - Univ. Tipografija, Kiev, 98 p. (in Russian).

Kluk K. 1780 - Domestic and wild animals, in particular Polish, introduction to natural history and economy. Vol. 3 Drukarnia J. K. Mości i Rzeczypospolitey u xx. Scholarum Piarum, Warszawa, 308 p. (in Polish).

Kołodziejczyk J. 1957 - In search of the sources for the botanical herbal by Stefan Falimirz - Archiwum Historii Medycyny, 20(1-2): 35-44 (in Polish).

Kulmatycki W. 1931 - Úber das Vorkommen und die Biologie des Huchens in Czeremosz-Fluss - Verh. Int. Ver. teoret. angew. Limnol 5: 354-396.

Löhr J.A.C. 1822 - Natural history for youth for school and home use. Transl. by A. Kuszański - Wilhelm Bogumił Korn, Wrocław, 350 p. (in Polish).

Leśniewski P.E. 1837 - Fisheries in Poland, or the natural history of the domestic fish - Zawadzki i Węcki, Warszawa, 360 p. (in Polish).

Muhamedagić S., Habibović E. 2013 - The state and perspective of Danube huchen (Hucho hucho) in Bosnia and Herzegovina - Arch. Pol. Fish. 21: 155-160.

[Nowicki M.] M.N. 1877 - The huchen in Czeremosz - Czas 184: 3 (in Polish).

Nowicki M. 1880a - To the fish names - Przyrodnik 2(9): 216-221, 2(13): 265-268 (in Polish).
Nowicki M. 1880b - Fish and waters of Galicia through the prism of domestic fisheries - Nakładem hr. Artura Potockiego, Drukarnia W. Korneckiego, Kraków, 96 p. (in Polish).

Nowicki M. 1889 - On the fish from the Vistula, Styr, Dniester, and Prut basins in Galicia - Drukarnia Czasu Fr. Kluczyckiego i Sp. Kraków, 55 p. (in Polish).

Petrycy S. 1613 - Instructions or science, how to behave during the plague - Drukarnia Mikołaja Loba, Kraków (in Polish).

Radtke G., Bartel R. 2011 - Occurence of trout Salmo trutta L. in lakes in northern Poland in a historical and environmental context - In: Ocena i ochrona bioróżnorodności wód (Eds) M. Jankun, G. Furgała-Selezniow, M. Woźniak, A.M. Wiśniewska, Faculty of Environmental Sciences and Fisheries, University of Warmia and Mazury, Olsztyn, Agencja Wydawnicza Argi: 75-90 (in Polish).

Rostafiński J. 1900 - Medieval natural history - Universitas Jagellonica, Kraków, 352 p. (in Polish).

Rozwadowski J. 1903 - Our fish. Huchen - Okólnik Rybacki 65. 182-193 (in Polish).

Rymarowicz L. 2011 - The saved world. Gertner family from Żabie (Płaj 40) - online http://karpaccy.pl/ocalony-swiat-gertnerzy-z-zabiego-plaj-40/ (accessed: 27 $7^{\text {th }}$ December 2014).

Rzączyński G. 1721 - Historia naturalis curiosa Regni Poloniae, Magni Ducatus Lithuaniae annexarumque provinciarum - Typis Coll. S.J., Sandomierz, 456 p.

Rzączyński G. 1742 - Auctuarium historiae naturalis curiosae Regni Poloniae, Magni Ducatus Lithuaniae annexarumquae provinciarum - Gdańsk, 504 p.

Sauvage H.-E. 1883 - La Grande Pęche (Les poissons) Librairie Furne Jouvet et $\mathrm{C}^{\mathrm{ie}}$, Paris, $314 \mathrm{p}$.

Schwenckfeld C. 1603 - Therio-Tropheum Silesiae, in quo Animalium, hoc est, quadrupedum, reptilium, avium, piscium, insectorum natura, vis \& usus sex libris perstringuntur - Impensis Davidis Alberti, imprimebat Nicolaus Sartorius, Legnica, 563 p.

Szuchiewicz W. 1902 - The land of the Huculs. Vol. 1 Muzeum im. Dzieduszyckich, Lwów, 373 p. (in Polish).

Wajgiel L. 1877 - A description of the city of Kołomyja Nakładem gminy miasta Kołomyi, Drukiem $\mathrm{H}$. Zadembskiego i spółki, Kołomyia, 114 p. (in Polish).

Wajgiel L. 1887 - On the Huculs. Ethnographic notes Pamiętnik Towarzystwa Tatrzańskiego 2: 49-86 (in Polish).

Witkowski A., Kapusta A. 2013 - Preface: Proceedings of the II International Hucho Symposium. Species of the genus Hucho Günther, 1866 - population status, conservation, biology, ecology, genetics, and culture, Łopuszna, Poland, September 19-22, 2012 - Arch. Pol. Fish. 21: 115-117.

Witkowski A., Bajić A., Treer T., Hegediš A., Marić S., Šprem N., Piria M., Kapusta A. 2013 - Past and present of and perspectives for the Danube huchen, Hucho hucho (L.), in the Danube basin - Arch. Pol. Fish. 21: 129-142. 